\title{
Evaluasi Penggunaan Aspirin Jangka Panjang terhadap Fungsi Ginjal Pasien Penyakit Jantung Koroner
}

\author{
Evaluation of Long-Term Use of Aspirin on Kidney Function of Coronary Heart Disease Patients
}

\author{
Ema Pristi Yunita ${ }^{1,2^{*}}$, Puji Astuti Nur Hidayanti ${ }^{3}$, Cholid Tri Tjahjono $^{4}$ \\ 1. Jurusan Farmasi, Fakultas Kedokteran, Universitas Brawijaya \\ 2. Pusat Studi Molekul Cerdas Berbasis Sumber Genetik Alami (SMONAGENES), Universitas Brawijaya \\ 3. Program Studi Sarjana Farmasi, Fakultas Kedokteran, Universitas Brawijaya \\ 4. Departemen Kardiologi, Fakultas Kedokteran, Universitas Brawijaya, RSUD Dr. Saiful Anwar \\ Submitted: 09-01-2020 Revised: 30-06-2020 Accepted: 28-09-2020 \\ Korespondensi : Ema Pristi Yunita : Email : emapristi@ub.ac.id
}

\begin{abstract}
ABSTRAK
Aspirin dosis-rendah (75-100 mg/hari) adalah terapi antiagregasi platelet bagi pasien penyakit jantung koroner (PJK) tertentu yang diberikan jangka panjang. Penelitian ini bertujuan untuk mengevaluasi penggunaan aspirin jangka panjang terhadap fungsi ginjal dengan melihat perubahan kadar kreatinin serum, blood urea nitrogen (BUN), dan klirens kreatinin pasien PJK. Metode penelitian yang digunakan yaitu analisis observasional kohort secara prospektif. Jumlah subjek penelitian yang memenuhi kriteria inklusi dan eksklusi sebanyak 37 pasien PJK pengguna aspirin dosis $80 \mathrm{mg} / \mathrm{hari}$ tanpa riwayat penyakit ginjal. Dilakukan pemeriksaan kadar kreatinin serum dan BUN pada bulan ke-1 dan bulan ke-3 dimulainya penelitian. Nilai klirens kreatinin pasien dihitung menggunakan rumus Cockcroft-Gault. Berdasarkan hasil penelitian, diperoleh rerata kadar kreatinin serum, BUN, dan klirens kreatinin pada bulan ke-1 dan bulan ke-3 masing-masing sebesar 1,03 \pm 0,27 mg/dL dan 1,03 $\pm 0,29 \mathrm{mg} / \mathrm{dL} ; 13,05 \pm 4,10$ $\mathrm{mg} / \mathrm{dL}$ dan 14,65 \pm 4,44 mg/dL; 73,16 \pm 18,14 mL/menit dan 72,92 \pm 19,76 mL/menit. Hasil uji t berpasangan menunjukan bahwa perbedaan rerata kreatinin serum, BUN, dan klirens kreatinin bulan ke1 dan bulan ke-3 tidak signifikan secara statistik ( $p>0,05)$. Hasil uji One Way ANOVA tentang pengaruh durasi penggunaan aspirin terhadap fungsi ginjal juga tidak signifikan secara statistik $(p>0,05)$ namun terdapat kecenderungan penurunan klirens kreatinin serta peningkatan kreatinin serum dan BUN. Penggunaan aspirin dosis-rendah dalam jangka panjang berpotensi menyebabkan penurunan fungsi ginjal jika dilihat dari adanya penurunan nilai klirens kreatinin serta peningkatan kreatinin serum dan BUN. Kata kunci: Aspirin dosis-rendah; BUN; kreatinin serum; penyakit jantung koroner
\end{abstract}

\section{ABSTRACT}

Low-dose aspirin (75-100 mg/day) is a long-term platelet antiaggregation therapy for certain coronary heart disease (CHD) patients. This study aims to evaluate the long-term use of aspirin on kidney function by examining the changes in the levels of serum creatinine, blood urea nitrogen (BUN), and creatinine clearance of CHD patients. The research method used was a prospective observational cohort analysis. The number of study subjects was $37 \mathrm{CHD}$ patients who took $80 \mathrm{mg} / \mathrm{day}$ of aspirin and never experienced kidney disease. Serum creatinine and BUN levels were examined in the $1^{\text {st }}$ and $3^{\text {rd }}$ month of the study. Patient creatinine clearance values were calculated using the Cockcroft-Gault equation. The results of the study showed that the mean levels of serum creatinine, BUN, and creatinine clearance on the $1^{\text {st }}$ and $3^{\text {rd }}$ month were $1.03 \pm 0.27 \mathrm{mg} / \mathrm{dL}$ and $1.03 \pm 0.29 \mathrm{mg} / \mathrm{dL} ; 13.05 \pm 4.10 \mathrm{mg} / \mathrm{dL}$ and $14.65 \pm 4.44$ $\mathrm{mg} / \mathrm{dL} ; 73.16 \pm 18.14 \mathrm{~mL} / \mathrm{min}$ and $72.92 \pm 19.76 \mathrm{~mL} / \mathrm{min}$, respectively. The paired t-test results showed that the differences in the mean of creatinine serum, BUN, and creatinine clearance on the $1^{\text {st }}$ and $3^{\text {rd }}$ month were not statistically significant $(p>0.05)$. The One Way ANOVA test results on the effect of the duration of aspirin use on kidney function were also not statistically significant $(p>0.05)$ however there is a tendency to decrease creatinine clearance and increase in serum creatinine and BUN. Long-term use of low-dose aspirin has the potential to cause a decrease in kidney function that is seen from a decrease in creatinine clearance as well as an increase in serum creatinine and BUN.

Keywords: Low-dose aspirin; BUN; serum creatinine; coronary heart disease 


\section{PENDAHULUAN}

Penyakit Jantung Koroner (PJK) merupakan penyakit kardiovaskular yang menyebabkan kematian nomor satu di Indonesia. PJK diprediksi akan terus bertambah hingga 23,3 juta dan menjadi penyebab kematian pada tahun $2030^{1}$. Aterosklerosis adalah alasan yang mendasari hampir semua penyebab PJK. Lesi lapisan lemak dapat berkembang menjadi plak yang rentan terhadap pecah atau erosi. Gangguan plak menginisiasi adhesi platelet dan agregasi pada permukaan vaskular yang terpapar dan aktivasi kaskade pembekuan yang mengarah pada proses aterotrombosis. Untuk itu, terapi antiagregasi platelet banyak digunakan untuk mencegah dan menghambat proses aktivasi/agregasi platelet dan aktivasi kaskade koagulasi ${ }^{2}$.

Upaya yang dilakukan oleh tenaga kesehatan untuk meningkatkan kualitas hidup pasien PJK yaitu pemberian terapi antiagregasi platelet salah satunya dengan aspirin. Analisis-meta oleh the Antithrombotic Trialists' Collaboration menunjukkan bahwa pemberian aspirin dapat menurunkan kejadian vaskular serius dan menurunkan laju mortalitas pada penyakit kardiovaskular maupun serebrovaskular ${ }^{3}$. Respons pasien PJK di salah satu rumah sakit di Indonesia juga masih bagus karena hasil penelitian oleh Yunita dkk. (2015) membuktikan bahwa tidak ada pasien yang mengalami resistensi terhadap aspirin ${ }^{4}$.

Aspirin bertindak sebagai agen asetilasi sehingga aspirin secara irreversibel menonaktifkan siklooksigenase (COX)-1 dan menekan pembentukan prostaglandin $\mathrm{H} 2$ (prekursor tromboksan A2). Aspirin menghasilkan kerusakan irreversibel dalam sintesis tromboksan untuk seumur hidup platelet yang terpapar (8-10 hari). Pemberian aspirin dosis-rendah dapat sepenuhnya menghambat COX-1 (menyebabkan efek jangka panjang) pada dosis harian yang diulang. Pencegahan yang dimediasi aspirin melibatkan penghambatan platelet. Sampai saat ini, aspirin telah dianggap sebagai obat yang mencegah trombosis arteri melalui penghambatan COX-1. Pedoman saat ini menetapkan peran aspirin dalam pencegahan primer kejadian kardiovaskular. Kejadian paling awal dalam pembentukan trombus adalah adhesi platelet diikuti oleh agregasi, aktivasi platelet, dan pelepasan granula. Kecuali untuk adhesi platelet, semua fungsi platelet ini dapat dihambat oleh aspirin. Oleh karenanya, aspirin mampu mengurangi risiko kejadian trombosis arteri ${ }^{5}$.

Aspirin menghambat pembentukan prostaglandin $\mathrm{H} 2 \quad\left(\mathrm{PGH}_{2}\right)$ melalui ikatan kovalen dengan Ser529 yang merupakan sisi aktif dari enzim COX-15. $\mathrm{PGH}_{2}$ diproduksi secara melimpah di ginjal. Dalam kondisi fisiologis, $\mathrm{PGH}_{2}$ berperan penting dalam pengaturan hemodinamik ginjal, pelepasan renin, serta keseimbangan air dan garam 6 . Penelitian oleh Sarsam dan Adeep (2009) menunjukkan bahwa aspirin dosis 300 $\mathrm{mg} /$ hari yang diberikan selama 4 minggu dapat menurunkan fungsi ginjal dan aspirin berpotensi menurunkan fungsi ginjal ${ }^{7}$. Segal et al., (2006) menyatakan bahwa pemberian aspirin dosis-rendah $(100 \mathrm{mg} /$ hari $)$ pada pasien lansia selama 2 minggu secara signifikan dapat memperburuk fungsi tubulus ginjal' ${ }^{8}$. Selain itu, terdapat penelitian lain di Indonesia tentang pengaruh penggunaan obat anti-inflamasi non-steroid (OAINS) pada fungsi ginjal pasien osteoartritis dengan durasi terapi minimal 4 minggu. Berdasarkan penelitian tersebut didapatkan hasil bahwa penggunaan OAINS selama 4-8 minggu dapat meningkatkan kreatinin serum dan BUN (blood urea nitrogen) pada pasien yang berusia > 60 tahun. Efek penggunaan aspirin jangka panjang terkait fungsi ginjal terutama pada pasien lansia memerlukan perhatian khusus ${ }^{8,9}$. Oleh karenanya, dilakukan penelitian ini untuk mengetahui pengaruh penggunaan aspirin dosis-rendah dalam jangka panjang terhadap fungsi ginjal pada pasien PJK karena belum banyak penelitian di Indonesia yang mengevaluasi tentang efek ini. 
METODE

\section{Desain penelitian}

Penelitian ini merupakan studi observasional kohort prospektif karena peneliti mengikuti subjek penelitian selama 3 bulan untuk melakukan pemeriksaan laboratorium dari sampel darah subjek penelitian. Pemeriksaan laboratorium dilakukan terhadap dua parameter yang diteliti yaitu kadar kreatinin serum dan BUN. Sementara itu, untuk parameter klirens kreatinin diperoleh dari perhitungan menggunakan rumus Cockcroft-Gault. Prosedur penelitian ini telah dikaji dan disetujui oleh Komisi Etik Fakultas Kedokteran Universitas Brawijaya Nomor 88/EC/KEPK-S1-FARM/03/2019.

\section{Sampel penelitian}

Berdasarkan perhitungan rumus besar sampel, jumlah pasien minimal yang diperlukan adalah 35. Pada penelitian ini diperoleh subjek sebanyak 37 pasien yang memenuhi kriteria inklusi dan eksklusi. Perhitungan rumus besar sampel yang digunakan dalam penelitian ini adalah sebagai berikut ${ }^{10}$ :

$$
\begin{gathered}
n 1=n 2=\left[\frac{(Z \alpha+Z \beta) S}{X 1-X 2}\right]^{2} \\
n 1=n 2=\left[\frac{(1,64+1,28) 0,02}{-0,01}\right]^{2} \\
\mathrm{n} 1=\mathrm{n} 2=34,11 \sim 35 \text { orang }
\end{gathered}
$$

Keterangan: $\mathrm{n} 1=\mathrm{n} 2=$ besar sampel minimal; $\mathrm{Z} \alpha=$ deviat baku alfa untuk $\alpha$ sebesar $5 \%$ untuk hipotesis satu arah (untuk $\alpha=0,05$ adalah 1,64); $\mathrm{Z} \beta=$ deviat baku beta untuk $\beta$ sebesar $10 \%$ (untuk $\beta=0,10$ adalah 1,28 ); $S=$ simpang baku dari dua kali selisih nilai antar kelompok $(S=0,02) ; \mathrm{X} 1=$ kadar kreatinin serum minggu pertama $0,88 \mathrm{mg} / \mathrm{dL}^{11} ; \mathrm{X} 2=$ kadar kreatinin serum minggu kedua 0,89 $\mathrm{mg} / \mathrm{dL}^{11} ; \mathrm{X} 1-\mathrm{X} 2=0,88-0,89=-0,01$

Kriteria inklusi penelitian yaitu laki-laki atau perempuan dewasa berusia $>26$ tahun; pasien didiagnosis PJK dan tidak memiliki riwayat penyakit ginjal kronis; belum terdiagnosis secara klinis mengalami penyakit renovaskular dan penyakit ginjal kronis; PJK bersifat stabil; mendapat terapi aspirin minimal 4 minggu; rutin mengonsumsi aspirin dosis-rendah (80 mg/hari); tidak memiliki kontraindikasi terhadap aspirin; serta bersedia berpartisipasi dalam penelitian. Sementara itu, kriteria eksklusi meliputi pasien yang mengalami lupus nefritis dan sepsis; menggunakan senyawa bersifat nefrotoksik seperti antibiotik golongan aminoglikosida, obat kemoterapi, dan agen radiokontras; memiliki riwayat penyakit gastritis; memiliki riwayat alergi terhadap aspirin; serta menggunakan OAINS selain aspirin. Komorbid pasien yang tidak memungkinkan disingkirkan dari penelitian meliputi hypertensive heart disease, hipertensi, gagal jantung, diabetes melitus tipe 2, Non-STElevation Infark Miokard, strok, dan osteoartritis.

\section{Pengumpulan data, lokasi penelitian, dan waktu penelitian}

Instrumen penelitian menggunakan data primer dan data sekunder. Data primer yang digunakan yaitu kadar kreatinin serum dan BUN. Pemeriksaan kadar kreatinin serum dan BUN tidak dilakukan secara rutin untuk pasien PJK di rumah sakit tempat dilakukannya penelitian (RSI UNISMA Kota Malang) sehingga peneliti melakukan pemeriksaan terhadap kedua parameter tersebut. Pengambilan sampel darah dilakukan di laboratorium RSI UNISMA Kota Malang terhadap pasien PJK sebanyak 2 kali yaitu bulan ke-1 dan ke-3 sejak dimulainya penelitian. Penelitian dilakukan pada bulan Maret-Juni 2019. Data sekunder merupakan data demografi pasien yang diambil dari rekam medis meliputi umur, jenis kelamin, riwayat penyakit, riwayat pengobatan, dan lama penggunaan obat. Data kadar kreatinin serum dan BUN tidak terdapat di dalam rekam medis pasien karena kedua parameter tersebut tidak diperiksa secara rutin untuk memantau fungsi ginjal pasien yang mendapat terapi aspirin jangka panjang. 
Tabel I. Data Demografi

\begin{tabular}{|c|c|c|}
\hline Parameter & Jumlah & Persentase $(\%)$ \\
\hline \multicolumn{3}{|l|}{ Umur } \\
\hline $31-40$ tahun & 1 & 2,70 \\
\hline 41-50 tahun & 8 & 21,62 \\
\hline 51-60 tahun & 11 & 29,73 \\
\hline 61-70 tahun & 15 & 40,54 \\
\hline 71-80 tahun & 2 & 5,41 \\
\hline Total & 37 & 100 \\
\hline \multicolumn{3}{|l|}{ Jenis Kelamin } \\
\hline Laki-Laki & 25 & 67,6 \\
\hline Perempuan & 12 & 32,4 \\
\hline Total & 37 & 100 \\
\hline \multicolumn{3}{|l|}{ Lama Penggunaan Aspirin } \\
\hline 1 bulan s.d $<6$ bulan & 21 & 56,8 \\
\hline 6-12 bulan & 8 & 21,6 \\
\hline$>12$ & 8 & 21,6 \\
\hline Total & 37 & 100 \\
\hline
\end{tabular}

\section{Analisis data}

Data pasien yang telah diklasifikasi disajikan dalam bentuk persentase. Data numerik diolah dalam bentuk desimal dan disajikan dalam bentuk rerata \pm simpangan baku (s.b). Selanjutnya, data-data tersebut ditampilkan dalam bentuk tabel.

Analisis penurunan fungsi ginjal dilakukan dengan membandingkan parameter-parameter terkait fungsi ginjal yaitu kreatinin serum, klirens kreatinin, dan BUN. Pemeriksaan dilakukan sebanyak dua kali yaitu pada bulan ke-1 dan ke-3. Sebelum dilakukan uji perbandingan, peneliti melakukan uji normalitas distribusi data dengan uji Shapiro-Wilk karena besar sampel $\leq 50$ subjek. Uji t berpasangan dilakukan untuk mengetahui perbedaan hasil pengukuran kadar kreatinin serum, klirens kreatinin, dan BUN pada bulan ke-1 dan ke-3. Sementara itu, uji One Way ANOVA dilakukan untuk melihat pengaruh durasi pemakaian aspirin yang dibagi dalam 3 kelompok waktu terhadap kadar kreatinin serum, klirens kreatinin, dan BUN. Nilai $p<0,05$ menunjukan hasil yang signifikan secara statistik.

\section{HASIL DAN PEMBAHASAN}

Terdapat 37 pasien yang bersedia menjadi subjek penelitian, terdiri dari 25 (67,6\%) pasien laki-laki dan 12 (32,4\%) pasien perempuan. Rata-rata umur pasien adalah 57,56 tahun. Lama penggunaan aspirin yang paling banyak adalah 1 bulan sampai dengan kurang dari 6 bulan. Data demografi pasien diuraikan pada Tabel I.

Aspirin dosis rendah merupakan terapi yang direkomendasikan untuk mencegah keparahan PJK. Dosis rendah yang digunakan untuk terapi antiagregasi platelet yaitu 75-325 $\mathrm{mg} /$ hari $^{12}$. Pada penelitian ini dosis aspirin yang digunakan sebesar $80 \mathrm{mg} / \mathrm{hari}$. Dari data demografi diperoleh subjek penelitian yang terbanyak adalah pasien dengan umur 61-70 tahun dengan rentang umur pasien secara keseluruhan adalah 39-75 tahun. Umur merupakan faktor risiko PJK sehingga dengan bertambahnya umur akan meningkatkan risiko terjadinya PJK. Semakin bertambah umur dapat meningkatkan kadar kolesterol total yang menyebabkan penumpukan kolesterol, meningkatkan risiko timbulnya plak yang menempel di dinding pembuluh 
Tabel II. Perbandingan Kadar Kreatinin Serum, BUN, dan Klirens Kreatinin pada Bulan ke-1 dan Bulan ke-3

\begin{tabular}{lcccc}
\hline \multirow{2}{*}{ Kategori } & \multirow{2}{*}{ N } & \multicolumn{2}{c}{ Rerata \pm simpangan baku } & \multirow{2}{*}{ p } \\
\cline { 3 - 4 } & & Bulan Ke-1 & Bulan Ke-3 & \\
\hline Kreatinin serum (mg/dL) & 37 & $1,03 \pm 0,27$ & $1,03 \pm 0,29$ & 0,963 \\
Klirens kreatinin (mL/menit) & 37 & $73,16 \pm 18,14$ & $72,92 \pm 19,76$ & 0,929 \\
BUN (mg/dL) & 37 & $13,05 \pm 4,10$ & $14,65 \pm 4,44$ & 0,052 \\
\hline
\end{tabular}

Uji t berpasangan; signifikan secara statistik jika $\mathrm{p}<0,05$

darah koroner, dan mengganggu aliran darah $^{13}$.

Mayoritas subjek dalam penelitian ini berjenis kelamin laki-laki karena laki-laki lebih berisiko mengalami PJK dibanding wanita. Salah satu kriteria inklusi dalam penelitian ini adalah pasien dengan PJK. Hal ini sesuai dengan hasil penelitian oleh Lansky et al., (2012) yang menunjukkan bahwa laki-laki lebih berisiko mengalami kematian akibat PJK IMA (infarktus miokardia akut) dibanding wanita. Hal ini disebabkan oleh laki-laki memiliki bentuk lesi plak aterosklerosis yang mudah ruptur, volume inti nekrosis yang lebih banyak, densitas kalsium yang lebih banyak, serta jaringan fibrosa dan fibrofatty yang lebih banyak dibanding wanita ${ }^{14}$. Berdasarkan penelitian oleh Bots et al., (2017) juga menunjukkan bahwa kematian PJK lebih tinggi pada laki-laki daripada perempuan sepanjang masa dewasa. Bots et al., (2017) menjelaskan bahwa laki-laki umumnya berkembang penyakit kardiovaskular pada umur yang lebih muda dan memiliki kecenderungan berkembang lebih tinggi menjadi PJK dibandingkan perempuan ${ }^{15}$. Seluruh pasien dalam penelitian ini mendapat aspirin karena aspirin dosis-rendah (75-100 $\mathrm{mg} /$ hari) dapat dipertimbangkan untuk pencegahan primer penyakit kardiovaskular aterosklerosis ${ }^{16}$. Namun demikian, tidak semua pasien yang mengonsumsi aspirin dapat terbebas dari efek samping berupa nyeri lambung. Berdasarkan penelitan tentang karakteristik penderita dispepsia mengemukakan bahwa perempuan lebih mudah mengalami dispepsia karena faktor psikologis dan hormon seks ${ }^{17}$. Pasien yang mengalami dispepsia atau keluhan nyeri lambung tidak dapat diberi terapi antiagregasi platelet berupa aspirin. Oleh karena itu, pada penelitian ini pasien laki-laki lebih banyak daripada pasien perempuan karena pasien perempuan diberi terapi antiagregasi platelet selain aspirin.

Dalam penelitian ini, penilaian fungsi ginjal pada pasien PJK yang mendapat terapi aspirin $80 \mathrm{mg} /$ hari menggunakan parameter kreatinin serum, BUN, dan klirens kreatinin. Didapatkan rerata kreatinin serum bulan ke-1 sebesar 1,03 $\pm 0,27 \mathrm{mg} / \mathrm{dL}$ dan bulan ke-3 sebesar 1,03 $\pm 0,29 \mathrm{mg} / \mathrm{dL}$; rerata nilai klirens kreatinin bulan ke-1 sebesar 73,16 $\pm 18,14$ $\mathrm{mL} /$ menit dan bulan ke-3 sebesar 72,92 $\pm 19,76$ $\mathrm{mL} / \mathrm{menit}$; rerata kadar BUN bulan ke-1 sebesar 13,05 $\pm 4,10 \mathrm{mg} / \mathrm{dL}$ dan bulan ke-3 sebesar 14,65 \pm 4,44 mg/dL. Kadar kreatinin serum, BUN, dan klirens kreatinin pada bulan ke-1 dan bulan ke-3 yang diuji dengan uji $t$ berpasangan menunjukan tidak ada perbedaan rerata yang signifikan secara statistik $(p>0,05)$ (Tabel II).

Hasil perbandingan kadar kreatinin serum, BUN, dan klirens kreatinin pasien pengguna aspirin dosis-rendah dalam jangka panjang tidak menunjukan perbedaan rerata yang signifikan. Pada parameter fungsi ginjal yaitu rerata nilai kreatinin serum dan BUN terdapat kecenderungan meningkat dari bulan ke-1 ke bulan ke-3. Rentang nilai kreatinin serum pada bulan ke-1 yaitu 0,76-1,30 mg/dL sedangkan pada bulan ke-3 yaitu 0,74-1,32 $\mathrm{mg} / \mathrm{dL}$. Dari rentang nilai tersebut terlihat bahwa kadar kreatinin serum tertinggi bulan ke-1 dan bulan ke-3 masing-masing adalah $1,30 \mathrm{mg} / \mathrm{dL}$ dan $1,32 \mathrm{mg} / \mathrm{dL}$. Hal ini 
menunjukkan jika penggunaan aspirin dosisrendah jangka panjang meningkatkan parameter kreatinin serum (nilai rujukan normal adalah 0,5-1,1 $\mathrm{mg} / \mathrm{dL}$ untuk perempuan dan $0,6-1,2 \mathrm{mg} / \mathrm{dL}$ untuk lakilaki).

Sementara itu, untuk nilai klirens kreatinin dari bulan ke-1 hingga bulan ke-3 tampak mengalami sedikit penurunan yaitu 0,33\%. Namun demikian, nilai klirens kreatinin dari hasil penelitian ini seperti ditunjukkan pada Tabel II termasuk rendah karena seperti diketahui bahwa rentang normal klirens kreatinin adalah 110-150 $\mathrm{mL} / \mathrm{menit}$ (untuk laki-laki) dan 100-130 $\mathrm{mL} /$ menit (untuk perempuan) ${ }^{18}$. Penurunan klirens kreatinin dapat mengindikasikan adanya penurunan fungsi ginjal dalam mengekskresi produk-produk buangan dan toksin seperti urea, kreatinin, dan asam urat ${ }^{19}$. Berdasarkan klasifikasi tingkat penyakit ginjal kronis dari pedoman K/DOQI (Kidney Disease Outcomes Quality Initiative of the National Kidney of the National Kidney Foundation), hasil penelitian ini dengan nilai klirens kreatinin pada bulan ke- 1 dan bulan ke-3 yang berada dalam rentang $60-90 \mathrm{~mL} /$ menit termasuk dalam penyakit ginjal kronis tingkat 2 yaitu kerusakan ginjal dengan penurunan laju filtrasi glomerulus ringan ${ }^{20}$. Parameterparameter fungsi ginjal dalam penelitian ini menunjukkan adanya potensi penurunan fungsi ginjal pada pasien yang menggunakan aspirin dosis-rendah dalam jangka panjang. Selain itu, proses penuaan pada lansia juga dapat berkontribusi menurunkan fungsi ginjal $^{21}$.

Dalam praktik klinik, kadar kreatinin serum dan BUN digunakan untuk mengetahui fungsi ginjal. Kreatinin serum merupakan produk metabolik dari massa otot dan diproduksi secara konstan kemudian diekskresi melalui ginjal. Untuk itu, kreatinin serum dapat dijadikan sebagai penanda jika terjadi penurunan fungsi ginjal. Namun demikian, kreatinin serum dapat dipengaruhi oleh massa otot, umur, jenis kelamin, dan aktivitas sehari-hari sehingga memungkinkan terjadi peningkatan atau penurunan tergantung faktor yang mempengaruhinya. Pemeriksaan BUN juga dapat digunakan untuk mengidentifikasi adanya kelainan pada ginjal. Urea serum atau BUN meningkat pada saat klirens ginjal menurun. BUN juga dapat meningkat pada kondisi yang tidak ada keterkaitannya dengan ginjal seperti saat dehidrasi dan diet tinggi protein. Rasio dari kreatinin dan BUN sangat berguna untuk mengetahui kelainan pada ginjal. Selain itu, BUN akan meningkat pertama kali saat ginjal mengalami kelainan ${ }^{19}$.

Selain kreatinin serum dan BUN, perhitungan klirens kreatinin juga terbukti dapat menjadi indikasi fungsi ginjal yang lebih baik daripada hanya melihat hasil pengukuran kreatinin serum karena perhitungan klirens kreatinin (rumus Cockcroft-Gault) menggunakan umur, tinggi badan, berat badan, jenis kelamin, dan nilai kreatinin serum ${ }^{22}$. Klirens kreatinin dapat dijadikan cerminan dari penilaian laju filtrasi glomerulus.

Berdasarkan data dari 37 pasien yang terlibat dalam penelitian ini, persentase lama penggunaan aspirin yang terbanyak adalah 1 bulan sampai kurang dari 6 bulan. Hasil uji One Way ANOVA terkait pengaruh lama penggunaan aspirin terhadap kadar kreatinin serum, BUN, dan klirens kreatinin menunjukan tidak terdapat perbedaan rerata yang signifikan (Tabel III). Hal ini menunjukkan jika pengaruh pemberian aspirin tidak dipengaruhi oleh lama penggunaan tetapi dapat dipengaruhi oleh faktor lain seperti besaran dosis yang diberikan ${ }^{7,23}$. Penelitian oleh Mahto (2017) menyebutkan bahwa pemberian aspirin dosis $100 \mathrm{mg} / \mathrm{hari}$ tidak menunjukkan adanya peningkatan yang signifikan terhadap kadar kreatinin serum dan urea. Akan tetapi, pemberian aspirin dosis $300 \mathrm{mg} / \mathrm{hari}$ menunjukan peningkatan yang signifikan pada kadar kreatinin serum dan urea ${ }^{23}$. Penelitian lain yang serupa menyebutkan bahwa pada pemberian aspirin dosis 300 $\mathrm{mg} /$ hari relatif menurunkan klirens kreatinin secara signifikan dibandingkan pemberian aspirin dosis $60 \mathrm{mg} /$ hari $^{22}$. Namun demikian, 
Tabel III. Pengaruh Lama Penggunaan Aspirin terhadap Kadar Kreatinin Serum, BUN, dan Nilai Klirens Kreatinin

\begin{tabular}{|c|c|c|c|c|c|c|c|c|}
\hline & & \multirow[t]{2}{*}{$\mathbf{N}$} & \multicolumn{2}{|c|}{$\begin{array}{c}\text { Kreatinin Serum } \\
(\mathrm{mg} / \mathrm{dL})\end{array}$} & \multicolumn{2}{|c|}{$\begin{array}{l}\text { Klirens Kreatinin } \\
\text { (mL/menit) }\end{array}$} & \multicolumn{2}{|c|}{ BUN (mg/dL) } \\
\hline & & & Rerata \pm s.b & $p$ & Rerata \pm s.b & $p$ & Rerata \pm s.b & p \\
\hline \multirow{3}{*}{$\begin{array}{c}\text { Lama } \\
\text { Penggunaan }\end{array}$} & $\begin{array}{c}1 \text { bulan } \\
\text { sampai < } \\
6 \text { bulan }\end{array}$ & 21 & $1,00 \pm 0,28$ & & $74,05 \pm 15,62$ & & $12,43 \pm 3,12$ & \multirow{3}{*}{0,320} \\
\hline & $\begin{array}{c}\text { 6-12 } \\
\text { bulan }\end{array}$ & 8 & $1,01 \pm 0,33$ & 0,720 & $73,75 \pm 22,37$ & 0,882 & $12,75 \pm 3,45$ & \\
\hline & $\begin{array}{l}>12 \\
\text { bulan }\end{array}$ & 8 & $1,10 \pm 0,20$ & & $70,25 \pm 21,95$ & & $15,00 \pm 6,41$ & \\
\hline
\end{tabular}

Uji One Way ANOVA; signifikan secara statistik jika $\mathrm{p}<0,05$

s.b: simpangan baku

jika fungsi ginjal dalam penelitian ini dilihat dari parameter klirens kreatinin terlihat bahwa pada semua kelompok lama penggunaan mengindikasikan adanya penurunan laju filtrasi glomerulus ringan dengan kecenderungan semakin lama penggunaan aspirin maka nilai klirens kreatinin juga semakin menurun yaitu 74,05 $\mathrm{mL} /$ menit (penggunaan 1 bulan sampai kurang dari 6 bulan) menjadi $73,75 \mathrm{~mL} /$ menit (penggunaan 6-12 bulan) kemudian menjadi $70,25 \mathrm{~mL} /$ menit (penggunaan lebih dari 12 bulan). Selain itu, pada parameter kreatinin serum juga menunjukkan kecenderungan meningkat yaitu $1,00 \mathrm{mg} / \mathrm{dL}$ pada durasi penggunaan aspirin 1 bulan sampai kurang dari 6 bulan kemudian meningkat menjadi $1,01 \mathrm{mg} / \mathrm{dL}$ pada durasi penggunaan aspirin 612 bulan dan meningkat lagi menjadi 1,10 $\mathrm{mg} / \mathrm{dL}$ pada durasi penggunaan aspirin lebih dari 12 bulan. Demikian juga pada parameter BUN juga menunjukkan peningkatan selama durasi terapi aspirin mulai dari $12,43 \mathrm{mg} / \mathrm{dL}$ meningkat menjadi $12,75 \mathrm{mg} / \mathrm{dL}$ dan kembali meningkat menjadi $15,00 \mathrm{mg} / \mathrm{dL}$.

\section{KETERBATASAN PENELITIAN}

Keterbatasan dalam penelitian ini adalah tidak banyak subjek penelitian dengan durasi penggunaan aspirin $80 \mathrm{mg} /$ hari yang lebih dari dua tahun. Jumlah subjek penelitian dengan durasi penggunaan aspirin lebih dari etdua tahun hanya 3 pasien $(8,11 \%)$.

\section{KESIMPULAN}

Berdasarkan penelitian yang telah dilakukan disimpulkan bahwa penggunaan aspirin dosis-rendah jangka panjang berpotensi menyebabkan penurunan fungsi ginjal dilihat dari adanya penurunan nilai klirens kreatinin serta peningkatan kreatinin serum dan BUN.

\section{DAFTAR PUSTAKA}

1. Kemenkes. Penyajian Pokok-Pokok Hasil Riset Kesehatan Dasar 2013 (Riskesdas 2013). Badan Penelitian dan Pengembangan Kesehatan Kementerian Kesehatan RI. http:// kesga.kemkes.go.id/images/pedoman/ Data Riskesdas 2013.pdf. Published 2013. Accessed April 25, 2020.

2. Badimon L, Padró T, Vilahur G. Atherosclerosis, platelets and thrombosis in acute ischaemic heart disease. Eur Hear J Acute Cardiovasc Care. 2012;1(1):60-74.

3. Piepoli MF, Hoes AW, Agewall S, Albus C, Brotons C, Catapano AL, et al., 2016 European guidelines on cardiovascular disease prevention in clinical practice. Eur Heart J. 2016;37(29):2315-2381. 
4. Yunita EP, Zulkarnain BS, Aminuddin $\mathrm{M}$. Aspirin resistance in coronary artery disease with hypertensive patients. Indones J Clin Pharm. 2015;4(1):28-38.

5. Mekaj YH, Daci FT, Mekaj AY. New insights into the mechanisms of action of aspirin and its use in the prevention and treatment of arterial and venous thromboembolism. Ther Clin Risk Manag. 2015;11:1449-1456.

6. Li Y, Xia W, Zhao F, Wen Z, Zhang A, Huang $S$, et al., Prostaglandins in the pathogenesis of kidney diseases. Oncotarget. 2018;9(41):26586-26602.

7. Sarsam J, Adeep Y. Assessing the effects of low dose aspirin on uricacid and renal function in healthy adults. Ann Coll Med. 2009;35(2):154-159.

8. Segal R, Lubart E, Leibovitz A, Iaina A, Caspi D. Renal effects of low dose aspirin in elderly patients. Isr Med Assoc J. 2006;8:679-682.

9. Yunita EP, Rochmawati PE. NSAID effects for kidney function in osteoarthritis patient. In: Nugraha AS, Dewi IP, Pratama ANW, et al., eds. 1st International Conference on Medicine and Health Sciences. Jember: Faculty of Pharmacy, Faculty of Dentristy, Faculty of Medicine, Faculty of Public Health, School of Nursing, University of Jember; 2016:38.

10. Dahlan MS. Besar sampel dan cara pengambilan sampel dalam penelitian kedokteran dan kesehatan. $3^{\text {rd }}$ Ed. Jakarta: Salemba Medika; 2009.

11. Caspi D, Lubart E, Graff E, Habot B, Yaron M, Segal R. The effect of minidose aspirin on renal function and uric acid handling in elderly patients. Arthritis Rheum. 2000;43(1):103-108.

12. Smith SC, Benjamin EJ, Bonow RO, Braun LT, Creager MA, Franklin BA, et al., AHA/ACCF secondary prevention and risk reduction therapy for patients with coronary and other atherosclerotic vascular disease: 2011 update a guideline from the American Heart Association and American College of
Cardiology Foundation. Circulation. 2011;124(22):2458-2473.

13. Kumar P. Coronary Artery Disease Clinical Medicine. $8^{\text {th }}$ Ed. Spain: International Edition; 2012.

14. Lansky AJ, Ng VG, Maehara A, Weisz G, Lerman A, Mintz GS, et al., Gender and the extent of coronary atherosclerosis, plaque composition, and clinical outcomes in acute coronary syndromes. J Am Coll Cardiovasc Imaging. 2012;5(3):S62-S72.

15. Bots SH, Peters SAE, Woodward M. Sex differences in coronary heart disease and stroke mortality: A global assessment of the effect of ageing between 1980 and 2010. BMJ Glob Heal. 2017;2:1-8.

16. Arnett DK, Blumenthal RS, Albert MA, Buroker $\mathrm{AB}$, Himmelfarb $\mathrm{CD}$, Goldberger ZD, et al., 2019 Guideline on the primary prevention of cardiovascular disease. Am Coll Cardiol. 2019:1-7.

17. Kim SE, Kim N, Lee JY, Park KS, Shin JE, Nam K, et al., Prevalence and risk factors of functional dyspepsia in health check-up population: a nationwide multicenter prospective study. J Neurogastroenterol Motil. 2018;24(4):603613.

18. Gowda S, Desai PB, Kulkarni SS, Hull VV, Math AAK, Vernekar SN. Markers of renal function tests. $N$ Am J Med Sci. 2010;2(4):170-173.

19. Gounden V, Jialal I. Renal Function Tests. StatPearls Publishing LLC. https://www.ncbi.nlm.nih.gov/books/N BK507821/. Published 2020. Accessed April 25, 2020.

20. Salgado JV, Neves FA, Bastos MG, França AK, Brito DJ, Santos EM, et al., Monitoring renal function: measured and estimated glomerular filtration rates-a review. Brazilian J Med Biol Res. 2010;43(6):528-536.

21. Hajivandi A, Amiri M. World kidney day 2014: Kidney disease and elderly. J Parathyr Dis. 2014;2(1):3-4. 
Evaluasi Penggunaan Aspirin Jangka Panjang terhadap Fungsi Ginjal Pasien

22. Lamb EJ. Kidney Fun In Clinical Chemistry and Molecular Diagnosis. $4^{\text {th }}$ Ed. America: Elsevier; 2010:797-831.
23. Mahto AK. Comparison of different doses of aspirin on renal function in elderly patients. Int J Med Heal Res. 2017;3(11):146-148. 